\title{
Regional Estimates of the Shadow Economy in Lithuania
}

\author{
Rita Remeikiene ${ }^{1}, Z_{0 l t a n}$ Rozsa $^{2}$, Ligita Gaspareniene ${ }^{3}$, Viktoras Chadysas ${ }^{4}$, Romualdas Ginevicius ${ }^{5}$ \\ ${ }^{1,3}$ Lithuanian Institute of Agrarian Economics \\ V. Kudirkos 18-2, 03105 Vilnius, Lithuania \\ E-mail.rita.remeikiene@laei.lt, ligita.gaspareniene@laei.lt
}

${ }^{2}$ School of Economics and Management in Public Administration in Bratislava

Furdekova 16, 85104 Bratislava, Slovakia

E-mail.zoltan@rozsa.sk

${ }^{4,5}$ Vilnius Gediminas Technical University

Sauletekio av. 11, 10223 Vilnius, Lithuania

E-mail.viktoras.chadysas@vgtu.lt,romualdas.ginevicius@vgtu.lt

cross $^{\text {ref }}$ http://dx.doi.org/10.5755/j01.ee.29.4.19438

The article is very topical and of high scientific value as it covers the problems of regional exclusion emphasized in the EU strategic documents. Regions suffer from social and economic exclusion, which, in turn, induces high unemployment and crime rates, and leads to the flourishing of smuggling. The aim of this article is to estimate the level of the shadow economy in the regions of Lithuania over the period 2012 to 2016. The topic is very relevant to such transition economies as Lithuania with huge separation between regions and large cities. Deep social problems in regions, lack of job places and absence of investment along with high emigration rate and intensive population's movement to the largest cities lead to the growth of crime rate and high scope of the shadow economy. Calculations performed under the MIMIC model have shown that the share of indirect taxes, average income, the cases of cigarette smuggling, population of women per 1000 men, the number of criminal offences, children in social risk families and the number of tourists are the main causes for the emergence and growth/decline of the shadow economy level. The novelty of the article lies in the calculations that reveal a significantly higher level of the shadow economy in the regions than at the country level. Therefore, it is recommended to make calculations at the regional level in order to select measures to more effectively fight with the "shadow". Identified reasons allow formulating the following recommendations for responsible authorities: increase efficiency in tax system, since current excise tax policy has a positive impact on the level of poverty, especially at regional level, deepening of social problems, which as a result contribute to the growth of shadow economy; encourage women occupancy and emancipation and attract funding from national and international projects, to promote equal rights in researched regions; increase the level of attractiveness and security level in cities, promote FDI to cities, and effectively use money from the EU Structural Funds.

Keywords: Causal Factors of the Shadow Economy; Indicators; Region; the MIMIC Model; Lithuania.

\section{Introduction}

Relevance of the topic. The fight against tax evasion, shadow economy, digital shadow economy and illegal employment in the regions has become one of the most important tasks of most countries over the past year, as the lack of information on the level of shadow economy in the regions does not allow to choose effective measures to eliminate the consequences of shadow economy (Gaspareniene et al., 2017). Identification of causes for the level of shadow economy, emergence and the spread of shadow economy in regions would enable to reduce other problems closely related with shadow, such as social exclusion between the cities and regions, higher unemployment rates in the regions, lower direct investment flows into the regions, lower average income, higher domestic and international migration compared to bigger cities. The analysis of scientific literature provides a variety of causal factors, which influence the level of shadow economy. The direct and indirect taxes are considered the key factors for the emergence of shadow economy across the country (based on Schneider's (2012) 22 studies, the increase in tax and social security burden on average 45-55\% increases the level of shadow economy), labour market factors (unemployment, employment, average income, minimum wage, labour market regulation), institutional factors including tax morale, satisfaction with existing government decisions, trust in government organizations, intensity of regulation, public sector services.

Until now, the level of the shadow economy for Lithuania at a country's level has been calculated by Schneider (2016), Statistics Lithuania for the year of 2012 - 2015, totalling to 15 percent (according to Statistics Lithuania) and up to 25,8 percent (according to Schneider). Various methodologies have been used to estimate the size of the shadow economy. To the best of the authors' knowledge, no research to estimate the level of the shadow 
Rita Remeikiene, Zoltan Rozsa, Ligita Gaspareniene, Viktoras Chadysas, Romualdas Ginevicius. Regional Estimates of the ...

economy in the separate regions of Lithuania, has been carried out thus far. Therefore, the purpose of this article is formulated as follows: on the basis of identification of the causal factors, to estimate the level of the shadow economy in the regional cities of Lithuania. For the fulfilment of the defined purpose, the following objectives were set: 1) to conduct the theoretical analysis of the studies that researched the level of the shadow economy in regions; 2) to provide the methodology of the Multiple Indicators Multiple Causes model (further - MIMIC model); 3) to estimate the level of the shadow economy in the regional cities of Lithuania over the period 2012 to 2016.

Importance of the research. The importance of the research manifests through estimation of the scopes of the shadow economy in small Lithuanian towns in different regions; the estimates of the shadow economy in these towns exceed the general scope of the shadow economy in the country. In addition, identification of the specific shadow economy determinants allowed to develop the efficient antishadow economy measures in particular regions.

The methods of research include systematic and comparative literature analysis, statistical analysis, and the MIMIC model.

\section{Literature Review: Summary of the Results from Previously Conducted Studies}

With reference to the variety of scientific sources, regional problems are topical not only due to the high probability of the cases of the shadow economy (Williams, 2011; Dias \& Samson, 2016, etc.), but also due to the fact that Foreign Direct Investment (further - FDI) inflows in regions are less intensive in comparison to FDI inflows in large cities, especially under the conditions of neo-liberal globalisation (Na, Lightfoot, 2006; Pick et al., 2010; Ramasamy et al., 2017; Li et al., 2018, etc.). Regions are facing such urgent problems as the lack of attractive work places (Williams, 2011), wage disparities (Liu et al., 2011), aging society (Gadsby \& Samson, 2016) and perverse practice of social taxation (Li et al., 2014), which proposes that poor regional development is impeding the entire development of a state.

Considering the above-explicated arguments, estimation of the size of the shadow economy at regional level would provide a better understanding of the real situation in a certain region (especially, as far as it concerns informal employment) and could contribute to the creation of appropriate policies for regional development. According to Tafenau et al. (2010), the funding from the European Union (further - the EU) Structural Funds and the Cohesion Fund highly depends on a region's Gross Domestic Product (further - GDP) per capita, compared to the EU average. With reference to the United Nations (2008), GDP calculations must cover all economic activities in the EU member states whether these activities are legal or illegal, hidden from or reported to public authorities. Hence, the data on the size of the shadow economy in regions could also serve as additional information for more accurate estimations of national and European GDPs.

Even though estimations of the size of the shadow economy in regions could contribute to targeted regional policies and prevention of tax evasion, scientific literature thus far has not been very rich in the studies on the topic of the regional informal economy (see Table 1).

Summary of the Results of Previous Studies on the Topic of the Regional Informal Economy

\begin{tabular}{|c|c|c|}
\hline Author(s), year & Region, method & Result received \\
\hline $\begin{array}{l}\text { Herwartz et al., 2015; Tafenau, et } \\
\text { al., 2010; Herwartz et al., } 2010\end{array}$ & $\begin{array}{l}\text { EU regions at the NUTS-2 } \\
\text { classification, the MIMIC model }\end{array}$ & $\begin{array}{l}\text { Unemployment rate, self-employment rate, tax wedge, Value Added } \\
\text { Tax (further - VAT), share of public employment, paid taxes }\end{array}$ \\
\hline Bilonizhko, 2006 & $\begin{array}{l}\text { Regions of Ukraine and Russia, the } \\
\text { MIMIC }\end{array}$ & $\begin{array}{l}\text { Tax pressure has a significant positive impact, agricultural and } \\
\text { industrial specializations both have significant positive impacts, } \\
\text { while unemployment rate has a significant negative impact on the } \\
\text { shadow economy in the regions under consideration }\end{array}$ \\
\hline Fertala, 2008 & $\begin{array}{l}\text { Administrative districts in Germany, } \\
\text { the technique of survival analysis - the } \\
\text { Gompertz-Makeham hazard model }\end{array}$ & $\begin{array}{l}\text { The positive impact of population density on the survival chances } \\
\text { was not as strong as is the share of foreign population resident in the } \\
\text { particular administrative district } \\
\text { The economic development of an administrative district also } \\
\text { influences the survival performance of new firms operating there. } \\
\text { Measured by the unemployment rate as well as the tax trade } \\
\text { collection rate, it was found a positive relationship between these } \\
\text { two indicators and the estimated hazard rate }\end{array}$ \\
\hline $\begin{array}{l}\text { Gonzalez-Fernandez, Gonzalez- } \\
\text { Velasco, } 2015\end{array}$ & $\begin{array}{l}\text { Spanish autonomous communities, } \\
\text { currency demand approach }\end{array}$ & $\begin{array}{l}\text { The size of the shadow economy ranges from } 18 \% \text { to } 30 \% \text { of } \\
\text { regional GDP, while an approximate mean value for the entire } \\
\text { territory amounts to } 25 \% \text {; the Personal Income Tax has the greatest } \\
\text { impact on the shadow economy in the region under research }\end{array}$ \\
\hline Kireenko et al., 2016 & $\begin{array}{l}\text { The Russian Federation and Ukraine, } \\
\text { factor analysis and the MIMIC }\end{array}$ & $\begin{array}{l}\text { The monetary income and formal employment show a weak } \\
\text { correlation in the Russian Federation, while they are closely related } \\
\text { in Ukraine }\end{array}$ \\
\hline Krakowski, 2005 & $\begin{array}{l}17 \text { countries in Latin America, the } \\
\text { MIMIC model }\end{array}$ & $\begin{array}{l}\text { The shadow economy is caused by labour regulation, index for } \\
\text { government effectiveness and tax rates, while low productivity } \\
\text { activities in urban areas and total employment serve as the indicators } \\
\text { of the shadow economy }\end{array}$ \\
\hline Buehn, 2011 & German regions, the MIMIC model & $\begin{array}{l}\text { An inferior local labour market and the burden of taxation } \\
\text { significantly contribute to the size of the shadow economy; more } \\
\text { affluent regions suffer from a smaller size of the shadow economy } \\
\text { compared to less affluent ones }\end{array}$ \\
\hline
\end{tabular}




\begin{tabular}{|l|l|l|}
\hline \multicolumn{1}{|c|}{ Author(s), year } & \multicolumn{1}{|c|}{ Region, method } & \multicolumn{1}{|c|}{ Result received } \\
\hline Bucek, 2017 & The Czech regions, the MIMIC model & $\begin{array}{l}\text { The number of people with at least one distraint and the burden of } \\
\text { taxation are important determinants of the shadow economy, but no } \\
\text { evidence of a significant impact of distraints on the size of the } \\
\text { shadow economy was disclosed; the regions surrounding large } \\
\text { cities, especially Prague, have, on average, smaller sizes of the } \\
\text { shadow economy in comparison to the borderlands }\end{array}$ \\
\hline Vorobyev, 2015 & $\begin{array}{l}\text { Russian regions, cross-section } \\
\text { regression model for electricity } \\
\text { consumption and augmented electricity } \\
\text { dynamics approach }\end{array}$ & $\begin{array}{l}\text { The main indicators of the shadow economy include corruption, } \\
\text { unemployment and dependency of regional budget on Federal } \\
\text { transfers; the share of the shadow economy in the Russian } \\
\text { Federation amounted to 55 percent in 2004, but diminished to 40 } \\
\text { percent in 2011 with only 16 from 65 regions having witnessed an } \\
\text { increase }\end{array}$ \\
\hline Schneider, 2012 & $\begin{array}{l}\text { Regions within the EU countries, the } \\
\text { MIMIC with spatial effects }\end{array}$ & $\begin{array}{l}\text { The extent of the shadow economy, quantified as a share of GDP, is } \\
\text { smallest in the regions of the Netherland (under 10 percent) and } \\
\text { highest in the regions in Greece (over 30 percent) }\end{array}$ \\
\hline Buszko, 2017 & $\begin{array}{l}\text { Warminsko-Mazurski and Kujawsko- } \\
\text { Pomorski Polish regions, the MIMIC } \\
\text { model }\end{array}$ & $\begin{array}{l}\text { The results disclosed a contradictory situation with the extent of the } \\
\text { shadow economy in both regions, which is explained by the } \\
\text { differences in their economic efficiency }\end{array}$ \\
\hline
\end{tabular}

The importance of regional factors in the total size of the informal economy was emphasised by Krakowski (2005) who researched the situation in 17 countries in Latin America and found that the regional informal economy is mainly caused by labour regulation index for government effectiveness and taxes rates, while low productivity activities in urban areas and total employment serve as the main indicators of this phenomenon. Tafenau et al. (2010) and Herwartz et al. (2010, 2015), who analysed the informal economy in the EU regions at the NUTS-2 classification, concluded that the main indicators of the regional shadow economy include unemployment rate, self-employment rate, tax wedge, VAT, the share of public employment and the share of paid taxes.

Fertala (2008) researched the problems of the informal economy in German administrative regions by employing the Gompertz-Makeham hazard model. The results of this study confirm the positive relationship between the unemployment rate and the tax trade collection rate as the measures of regional economic development. The situation of German regions was also researched by Buehn (2011) whose study disclosed that an inferior local labour market as well as the burden of taxation significantly contribute to the size of the shadow economy in the regions under consideration, while a better enforcement of tax rules and regulations has the potential to deter informal activities. The results of the study also showed that the districts in the affluent south suffer from a smaller (on average) size of the shadow economy in comparison to the other regions of the country.

Gonzalez-Fernandez and Gonzalez-Velasco (2015), who analysed the shadow economy in the Spanish autonomous communities over the period 1987-2010, estimated that the size of the shadow economy in the regions under research ranges from $18 \%$ to $30 \%$ of regional GDP with Andalucía demonstrating the highest, and Islas Canarias - the lowest values of the shadow economy. It was found that the Personal Income Tax had the greatest impact on the shadow economy in the area under research.

Bilonizhko (2006) analysed the causes of the shadow economy in the regions of the Russian Federation and Ukraine over the period from 2001 to 2003. From the list of the selected causes, tax pressure, specialization of a region (industrial or agricultural) and unemployment rate were found to be significant in most specifications of the MIMIC model. Real Gross Regional Product (further GRP) per capita and employment rate are used as the indicators of the shadow economy in the model developed. The author concludes that tax pressure has a significant positive impact, agricultural and industrial specializations both have significant positive impacts, while unemployment rate has a significant negative impact on the shadow economy in the regions under consideration. The findings are explained by the fact that today's shadow economy is mostly made up of the officially employed economic agents who use different schemes to avoid taxation. Kireenko et al. (2016), who also researched the issues of the shadow economy in the regions of the Russian Federation and Ukraine by applying the methods of factor analysis and the MIMIC, provided the opposite results, with reference to which the monetary income and formal employment show a weak correlation in the Russian Federation, while they are closely related in Ukraine. The study also revealed that the indices for the standard and quality of living can be regularly explained by the impact of various factors, which, in its turn, indicates a gap between the economic and societal components in the functioning of the states under research. The MIMIC model helped to estimate that the level of the informal economy in the Russian Federation varied from 48 to $62 \%$ of GRP at the regions under consideration over the period from 2000 to 2013. Slightly different results were obtained by Vorobyev (2015), whose estimations propose that the share of the shadow economy in the Russian Federation amounted to 55 percent in 2004, but diminished to 40 percent in 2011. With reference to the research results, only 16 from 65 regions under consideration witnessed an increase in the share of the shadow economy over the period from 2004 to 2011. The average share of the informal economy was estimated at 40 $\%$ with the standard deviation of 18 percentage points. The high positive correlation between the size of the shadow economy and such proxies as corruption, unemployment and, especially, dependency of regional budget on Federal transfers was established.

Bucek (2017) investigated the size and development of the shadow economy in the regions of the Czech Republic over the period from 2005 to 2014. The research was aimed at assessing the plausible impact of the labour 
market indicators, the number of people with at least one distraint, and the burden of taxation on the size of the shadow economy in the regions under consideration. The results of the research showed that namely the number of people with at least one distraint and the burden of taxation are important determinants of the shadow economy, but no evidence of a significant impact of distraints on the size of the shadow economy was disclosed. The study also revealed that the regions surrounding large cities, especially Prague, have, on average, smaller sizes of the shadow economy in comparison to the borderlands.

Schneider (2012) followed the MIMIC approach with spatial effects to estimate the extent of the shadow economy in the regions within the EU countries in 2007 and 2008. The results of his research revealed that the extent of the shadow economy, quantified as a share of GDP, is smallest in the regions of the Netherland (under 10 percent) and highest in the regions in Greece (over 30 percent), which calls for regional diversification of the measures directed against shadow activities.

Following the same MIMIC approach, Buszko (2017) presented the appraisal of the shadow economy in Warminsko-Mazurski and Kujawsko-Pomorski Polish regions in 2006, 2011 and 2016. The results of the study showed that the size of the shadow economy in the latter region was higher than that in the former one in the first year under consideration, but it declined in the following years. A contradictory situation was observed in Warminsko-Mazurski region. Such significant differences in the size of the shadow economy in separate regions are said to have been caused by the differences in their economic efficiency (Kujawsko-Pomorski region proved to be more economically effective, which leaves less space for shadow activities in it).

Although several methods can be applied to assess the scale of the shadow economy, only few of them can be used at the regional level. For example, certain methods cannot be used for calculations due to data inaccessibility: money demand or consumption of electricity are often used as the major variables of shadow economy, hence they are not defined as national territorial subunits (Tafenau et al., 2010). Due to this reason, the MIMIC model has been chosen for the regional analysis. The following hypothesis is made in the empirical part, that the size of the shadow economy in regions is much bigger in comparison to that in big cities since regions are more affected by high taxes, poor employment opportunities and an excessive public sector.

Many methodologies for the assessment of the shadow economy and its indicating factors exist in scientific literature (Schneider \& Enste, 2000; Kazemier, 2006; Pickhardt \& Shinnick, 2008; Adair, 2012). The MIMIC (Multiple-Indicators-Multiple-Causes) method is the most frequently used out of all methodologies. The models, having monetary value, allow assessing the level of the shadow economy directly. The majority of them are based on the Quantity Theory of Money, which has been practically implemented for the first time by Cagan (1958). After a couple of decades, Gutmann (1977) created a simpler, non-econometric model, based on the monetary approach, which was applied in the USA. Gutmann (1977) calculated the ratio between cash and deposits, assuming that the circulation of cash is the same in both the formal and informal shadow economy. Obviously, each method has its advantages and disadvantages. For example, one advantage of the MIMIC model is that the model allows to check the statistical significance of causal factors which are not directly included in monetary-based models, such as unemployment, partial employment, self-employment and other variables, that may affect the shadow economy (corruption, laws). However, the MIMIC model has been criticised by Breusch (2005a, 2005b, 2005c, 2005d) who stated that this is not only a problematic method from an econometric aspect, but it also requires the procedures which would turn ordinary values into meaningful ones. What is more, there exists no theoretical basis which would help to distinguish the relationships between the indicative and causative factors. Therefore, the MIMIC model becomes very sensitive to the variables included in the calculations. Despite the criticisms outlined above, the MIMIC model is the only alternative to monetary models, since in most of cases there is a problem with the availability of data (Mauleon \& Sarda, 2017).

Despite the criticism, a number of researchers have applied the MIMIC model to calculations of the shadow economy: for individual countries, such as New Zealand (Giles, 1999), Canada (Giles \& Tedds, 2002), Italy (Dell'Anno, 2003), Spain (Alanon-Pardo \& GomezAntonio, 2005), India (Chaudhuri et al., 2006), Portugal (Dell'Anno, 2007), the USA (Dell'Anno \& Solomon, 2008) and others. As it can be seen from the literature analysis, the size of the shadow economy at a country level has been studied by many scientists (Schneider, 2007; Schneider et al., 2015; Medina \& Schneider, 2017; Schneider \& Williams, 2016), although in reality the size of the shadow economy may vary considerably within different regions of the same country.

Summarising, it can be concluded that the estimation of the size of the shadow economy in regions requires more detailed information, which is not always publicly available or it takes more time and resources to collect it. Undoubtedly, the estimation of the size of the shadow economy in separate regions would allow identifying the problems associated with a certain region, which, in its turn, may decrease the possibility of "the shadow" prosperity.

\section{Research Methodology: the MIMIC Model}

The MIMIC multiple causes model is considered the most comprehensive methodology developed for estimation of the size of the shadow economy (Schneider \& Buehn, 2016; Nchor \& Adamec, 2015). In this model, the shadow economy is considered as a latent variable, which, on one side, is related to the set of observed indicators, and on the other side - to the set of causal variables, which have a considerable impact on the multitude of the researched phenomenon.

When a sufficient quantity of indicative and causal data is available, the model is developed by employing pretty standard procedures of econometrics.

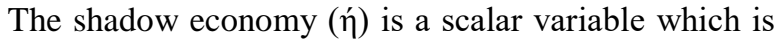
linearly described by a set of directly observed variables $\mathrm{X}_{1}, \mathrm{X}_{2}, \ldots, \mathrm{X}_{\mathrm{q}}$ and scalar random noise $(\zeta)$. 


$$
\eta^{\prime}=\mathrm{Y}_{1} \mathrm{X}_{1}+\mathrm{Y}_{2} \mathrm{X}_{2}+\ldots \mathrm{Y}_{q} \mathrm{X}_{q}+\zeta
$$

The latent (hidden) variable (ท́), in turn, directly describes endogenous variables $\mathrm{Y}_{1}, \zeta \mathrm{Y}_{2}, \ldots, \mathrm{Y}_{\mathrm{p}}$, which are dependent on the levels of scalar noise $\varepsilon_{1}, \varepsilon_{2}, \ldots, \varepsilon_{\mathrm{p}}$ :

$$
\begin{aligned}
y_{1}= & \lambda_{1} \eta^{\prime}+\varepsilon_{1} \\
y_{2}= & \lambda_{2} \eta^{\prime}+\varepsilon_{2} \\
& (\ldots) \\
y_{p}= & \lambda_{p} \eta^{\prime}+\varepsilon_{p}
\end{aligned}
$$

Structural noise $(\zeta)$ and estimation errors $\varepsilon$ have a normal distribution and are linearly independent. Then, the following marking is introduced:

$\mathrm{X}^{\mathrm{T}}=\left(\mathrm{x}_{1}, \mathrm{x}_{2}, \ldots, \mathrm{x}_{\mathrm{q}}\right)-$ observed exogenous variables (causes);

$\mathrm{Y}^{\mathrm{T}}=\left(\mathrm{Y}_{1}, \mathrm{Y}_{2}, \ldots, \mathrm{Y}_{\mathrm{q}}\right)-$ structural parameters (structural model);

$\mathrm{y}^{\mathrm{T}}=\left(\mathrm{y}_{1}, \mathrm{y}_{2}, \ldots, \mathrm{y}_{\mathrm{q}}\right)-$ observed endogenous variables (indicators);

$\lambda^{\mathrm{T}}=\left(\lambda_{1}, \lambda_{2}, \ldots, \lambda_{\mathrm{q}}\right)-$ structural parameters (estimation model);

$\varepsilon^{\mathrm{T}}=\left(\varepsilon_{1}, \varepsilon_{2}, \ldots, \varepsilon_{\mathrm{q}}\right)-$ estimation errors;

$\mathrm{v}^{\mathrm{T}}=\left(\mathrm{v}_{1}, \mathrm{v}_{2}, \ldots, \mathrm{v}_{\mathrm{q}}\right)$ - standard deviation of estimation errors.

Formulas (1) and (2) can be rewritten as:

$$
\begin{gathered}
\eta_{t}^{\prime}=\mathrm{Y}^{T} x_{t}+\zeta_{t} \\
y_{t}=\lambda \eta_{t}^{\prime}+\varepsilon_{t}
\end{gathered}
$$
$\Theta^{2}$.

It is presumed that $\mathrm{E}\left(\zeta \varepsilon^{\mathrm{T}}\right)=0, \mathrm{E}\left(\zeta^{2}\right)=\sigma^{2}$, and $\mathrm{E}\left(\varepsilon \varepsilon^{\mathrm{T}}\right)=$

$\Theta_{\text {pxp }}$ refers to a diagonal matrix with $\mathrm{v}$, which is inherent to its diagonal.

The model can be converged into a reduced form, i.e. into a function of observed variables:

$$
y=\lambda\left(\mathrm{Y}^{\mathrm{T}} x+\zeta\right)+\varepsilon=\Pi x+v
$$

Here $\Pi=\lambda \mathrm{Y}^{\mathrm{T}}$, and $\mathrm{v}=\lambda \zeta+\varepsilon$.

This way, the matrix of model covariation is developed:

$$
\sum=\left(\lambda\left(\mathrm{Y}^{T} \Phi \mathrm{Y}+\Psi\right)\right) / \Phi \mathrm{Y} \lambda^{T}+\Theta_{\varepsilon} \lambda \mathrm{Y}^{T} \Phi / \Phi
$$

The latent (hidden) variable (ท́) is invisible, and its value remains unknown. The other parameters of the model have to be evaluated by analysing the links between the observed variables in the dispersion and covariation. The main aim is to find the values of parameters $\mathrm{Y}$ and $\lambda$, and the estimate $\Sigma$.

Percent from GDP is calculated using the following equation (Schneider et al., 2009):

$$
\hat{\eta}_{t}=\frac{\tilde{\eta}_{t}}{\tilde{\eta}_{2000}} \eta *_{2000}
$$

where $\hat{\eta}_{t}$ denotes the value of MIMIC index at $\mathrm{t}, \tilde{\eta}_{2000}$ is the value of this index in the base year 2000, and $\eta *^{2000}$ is the exogenous estimate (base value) of the shadow economies in 2000.

The MIMIC model was developed for estimation of the size of the shadow economy. The shadow economy is a latent variable, the values of which are unknown. For this reason, estimations cannot be based on time series or regular regression models. The authors of this article did not detect any other models that would allow to estimate the size of the shadow economy with high accuracy. The size of the shadow economy for Lithuanian regions with application of the MIMIC model has never been estimated before. In the context of this article, the causal factors are treated as the factors that may have an impact on the size of the shadow economy, i.e. the factors that may increase or decrease it. The indicators are the factors that are affected by the shadow economy. The specific factors of the shadow economy include the factors that affect the size of the shadow economy in regions.

\section{Results of the Empirical Research: the Assessment of the Regional Shadow Economy in Lithuania}

The purpose of empirical research is to assess the level of the shadow economy in separate regions of Lithuania (Aukstaitija, Dzukija, Suvalkija, Zemaitija) over the period 2012 to 2016. For fulfilment of this purpose, 126 variables were collected. In order to reduce collinearity, 19 latent

\begin{tabular}{|c|c|c|c|c|c|c|c|}
\hline & \multirow{2}{*}{$N$} & \multirow{2}{*}{ Mean } & \multirow{2}{*}{ Std. Deviation } & \multicolumn{2}{|c|}{ Missing } & \multicolumn{2}{|c|}{ No. of Extremes ${ }^{a}$} \\
\hline & & & & Count & Percent & Low & High \\
\hline X3 & 92 & 543,76957 & 73,671768 & 0 &, 0 & 0 & 1 \\
\hline $\mathrm{X} 22$ & 92 & 259,57459 & 17,566782 & 0 & 0 & 0 & 0 \\
\hline $\mathrm{X} 11$ & 92 & 6,19463 & 3,444509 & 0 & ,0 & 0 & 3 \\
\hline $\mathrm{X} 13$ & 89 & 345,24719 & 48,001960 & 3 & 3,3 & 0 & 0 \\
\hline X19 & 92 & 367,92981 & 123,068317 & 0 & 0 & 0 & 1 \\
\hline $\mathrm{X} 18$ & 92 & 121,03750 & 13,357341 & 0 & ,0 & 0 & 0 \\
\hline $\mathrm{X} 20$ & 92 & 65,37935 & 11,349024 & 0 & ,0 & 0 & 0 \\
\hline $\mathrm{Y7}$ & 92 & 29,21619 & 26,349149 & 0 & ,0 & 0 & 4 \\
\hline InfCommEmp & 82 & 4,71584 & 4,763216 & 10 & 10,9 & $\theta$ & 8 \\
\hline ValueMinQuar & 92 & 13,27262 & 5,581269 & 0 & 0 & 0 & 5 \\
\hline $\mathrm{X} 2$ & 92 & ,66397 &, 111559 & 0 & ,0 & 2 & 13 \\
\hline Y2 & 92 & 58,67510 & 20,039624 & 0 &, 0 & 0 & 8 \\
\hline $\mathrm{X} 12$ & 87 & 111,52332 & 47,471042 & 5 & 5,4 & 0 & 0 \\
\hline $\mathrm{X} 1$ & 86 &, 18971 &, 782495 & 6 & 6,5 & 0 & 0 \\
\hline
\end{tabular}
variables were calculated, and 13 different variables were selected for 18 cities from four regions of Lithuania. With reference to the data of Phillip Morris International (2016), the flows of smuggled cigarettes in these 18 cities are most intensive, which served as the main criterion of inclusion of the cities in the research. Many missing values appeared among the collected data (see Table 2).

Table 2

Statistics of Causal and Indicative Factors 
Rita Remeikiene, Zoltan Rozsa, Ligita Gaspareniene, Viktoras Chadysas, Romualdas Ginevicius. Regional Estimates of the ...

\begin{tabular}{|c|c|c|c|c|c|c|c|}
\hline & \multirow{2}{*}{$N$} & \multirow{2}{*}{ Mean } & \multirow{2}{*}{ Std. Deviation } & \multicolumn{2}{|c|}{ Missing } & \multicolumn{2}{|c|}{ No. of Extremes ${ }^{a}$} \\
\hline & & & & Count & Percent & Low & High \\
\hline $\mathrm{X} 10$ & 80 & ,, 04696 & ,866593 & 12 & 13,0 & $\theta$ & $\theta$ \\
\hline $\mathrm{X} 9$ & 41 & -25402 &, 873571 & 51 & 55,4 & 4 & $z$ \\
\hline $\mathrm{X} 7$ & 92 &,- 15359 & ,954790 & 0 &, 0 & 0 & 6 \\
\hline $\mathrm{X} 4$ & 92 & ,31036 & ,946745 & 0 &, 0 & 0 & 0 \\
\hline Y5 & 92 & ,10506 & ,976491 & 0 &, 0 & 0 & 0 \\
\hline $\mathrm{X} 8$ & 72 &, 14249 & 1,008078 & 20 & 21,7 & $\theta$ & $\theta$ \\
\hline $\mathrm{X} 14$ & 89 & $\begin{array}{l}-20747 \\
\end{array}$ & ,748763 & 3 & 3,3 & 2 & 4 \\
\hline $\mathrm{X} 15$ & 92 & 02645 & 1,028522 & 0 & 0 & 0 & 0 \\
\hline L18 & 78 &, 04270 &, 869500 & 14 & 15,2 & $z$ & 7 \\
\hline $\mathrm{Y} 1$ & 86 & ,09630 & ,899249 & 6 & 6,5 & 0 & 2 \\
\hline $\mathrm{X} 5$ & 92 &,- 03662 & ,954338 & 0 & 0 & 0 & 1 \\
\hline $\mathrm{X} 17$ & 81 &, 08932 &, 962769 & 11 & 12,0 & 3 & $\theta$ \\
\hline $\mathrm{X} 6$ & 88 &, 05125 & 1,029988 & 4 & 4,3 & 4 & 1 \\
\hline $\mathrm{Y} 3$ & 92 & ,02844 & ,765894 & 0 &, 0 & 0 & 1 \\
\hline Y6 & 80 & ,07824 & 1,386817 & 12 & 13,0 & $z$ & 4 \\
\hline Y4 & 77 &, 05464 & ,904846 & 15 & 16,3 & 4 & 4 \\
\hline $\mathrm{X} 16$ & 57 &,- 02699 &, 896285 & 35 & 38,0 & $\theta$ & 4 \\
\hline L9 & 89 & ,06078 & ,920059 & 3 & 3,3 & 0 & 15 \\
\hline
\end{tabular}

Data from 2016 have been removed from all collected data, since the major part of variables have been with missing values. Due to huge number of missing values we remove variables, whose missing values exceed $10 \%$ (see Table 2, values are crossed out). We also remove records 73 and 57, since 10 meanings are missing in each of them. Remaining missing values are recovered using average method, which is the value of the corresponding averaged variable instead of the missed values.

The MIMIC model is constructed from the remaining variables by employing the LISREL program. It was identified, that the LISREL, according to the number of the records available, allows to include 11 causal variables (X1, X2, X3, X4, X5, X6, X7, X11, X12, X13, X14) and 5 indicative variables (Y1, Y2, Y3 Y5, Y7), where X1 - L1,

X2 - IndiTaxShare, X3 - AverageEarnings, X4 - L13, X5 - L2, X6 - L4, X7 - L12, X8 - L15, X9 - L11, X10 L10, X11 - Net migration, X12 - Industry employee, X 13 - Old recipients, X 14 - L16, X 15 - L17, X 16 - L8, X 17 L3, X 18 - number of pupil, X 19 - Number of School meals, X 20 - Propreschool, X21 - Proportion of children in preschool education, X22 - Hospitalized, Y1 - L 19,

Y2 - E_SME_E, Y3 - L5,Y4 - L7, Y5 - L14,Y6 - L6,Y 7 - Inheritance taxes.
Concordance of the model is indicated by the following indicators:

AIC (Akaike) - the lower the value is, the better the model is;

RMSEA (Root Mean Square Error of Approximation) - is good, when RMSEA is less than 0,1 ;

GFI (Goodness of Fit Index) - the model is well compatible with data, when GFI is close to 0,95 ;

NFI (Normed Fit Index) - is good, when NFI is close to 0,95 ;

A summary of different models with the estimates and different test values has been presented in Table 3. The module $\mathrm{t}$ of $\mathrm{t}$ value, marked in red, is lower than 1.96, which shows that the indicators are not significant and need to be eliminated from the model; in addition, the indicators of the model concordance (RMSEA is more than 0,1 ; GFI and NFI are less than 0,95) show that the model is not applicable.

All non-significant causative variables were further eliminated (see Table 4).

Finally, we removed one insignificant indicative variable Y7 (see Table 5).

MIMIC 11-1-5 Summary of Model with Estimates Received

Table 3

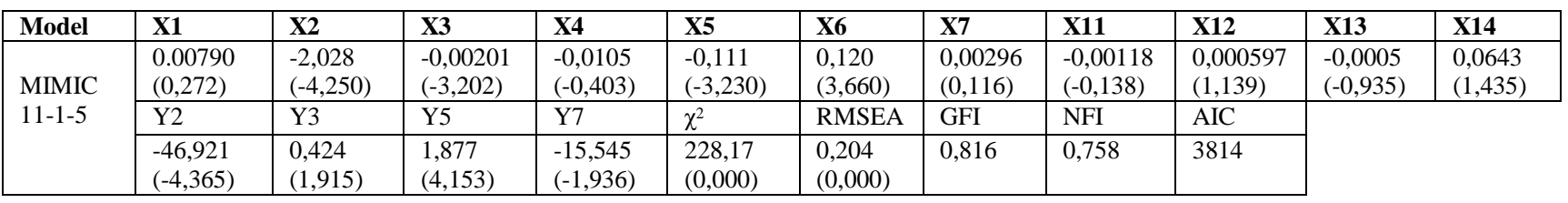

Note:

$t$-statistic are given in parentheses.

* Means $\mid$ t-statistic $\mid>1,96$.

MIMIC 4-1-5 Verifying Model Assumptions by Removing Irrelevant Causative Variables

Table 4

\begin{tabular}{|c|c|c|c|c|c|c|c|c|c|}
\hline Model & & $\mathrm{X} 2$ & $\mathrm{X3}$ & & $\mathrm{X5}$ & X6 & & & \\
\hline \multirow{3}{*}{$\begin{array}{l}\text { MIMIC 4- } \\
1-5\end{array}$} & & $\begin{array}{c}-1,542 \\
(-3,028) \\
\end{array}$ & $\begin{array}{c}-0,00075 \\
(-2,540) \\
\end{array}$ & & $\begin{array}{l}-0,0860 \\
(-2,726) \\
\end{array}$ & $\begin{array}{l}0,0867 \\
(2,864) \\
\end{array}$ & & & \\
\hline & Y2 & Y3 & Y5 & Y7 & $\chi^{2}$ & RMSEA & GFI & NFI & AIC \\
\hline & $\begin{array}{r}-64,772 \\
(-3,099) \\
\end{array}$ & $\begin{array}{c}0,605 \\
(1,976) \\
\end{array}$ & $\begin{array}{c}2,231 \\
(2,933) \\
\end{array}$ & $\begin{array}{l}-16,596 \\
(-1,612) \\
\end{array}$ & $\begin{array}{c}49,85 \\
(0,000) \\
\end{array}$ & $\begin{array}{c}0,161 \\
(0,000) \\
\end{array}$ & 0,905 & 0,875 & 1946 \\
\hline
\end{tabular}


MIMIC 4-1-4 Verifying Model Assumptions after the Removal of Insignificant Indicative Factors

\begin{tabular}{|c|c|c|c|c|c|c|c|c|}
\hline Model & & $\mathbf{X} 2$ & $\mathbf{X 3}$ & X5 & X6 & & & \\
\hline \multirow{3}{*}{$\begin{array}{l}\text { MIMIC 4- } \\
\text { 1-4 }\end{array}$} & & $\begin{array}{c}-2,167 \\
(-2,926) \\
\end{array}$ & $\begin{array}{c}-0,00126 \\
(-2,614) \\
\end{array}$ & $\begin{array}{l}-0,0955 \\
(-2,748) \\
\end{array}$ & $\begin{array}{l}0,0911 \\
(2,858) \\
\end{array}$ & & & \\
\hline & $\mathrm{Y} 2$ & Y3 & $\mathrm{Y} 5$ & $\chi^{2}$ & RMSEA & GFI & NFI & AIC \\
\hline & $\begin{array}{l}-49,707 \\
(-2,999) \\
\end{array}$ & $\begin{array}{c}0,765 \\
(2,091) \\
\end{array}$ & $\begin{array}{c}2,414 \\
(3,010) \\
\end{array}$ & $\begin{array}{c}15,59 \\
(0,0486) \\
\end{array}$ & $\begin{array}{c}0,103 \\
(0,119) \\
\end{array}$ & 0,963 & 0,957 & 1268 \\
\hline
\end{tabular}

It is obvious, that MIMIC 4-1-4 model is the most suitable to estimate the level of the shadow economy:

It can be written down as the following mathematical expression:

Shadow $=-2.167 * \mathrm{X} 2-0.00126 * \mathrm{X} 3-0.0955 * \mathrm{X} 5+$ $0.0911 * \mathrm{X} 6$

Where X2 - IndiTaxShare; X3 - AverageEarnings; X5 - L2; X6 - L4.

Indicative factors received are the following:

Y1 - L19 (the number of new small and medium-sized enterprises, children at social risk families, receiving support at day care centres, taxes, paid by a single resident), Y2 E_SME_E, Y3 - L5 (cases of violence in families, registered with the police; number of emigrants/immigrants; net migration, number of trucks), Y5 - L14 (municipal budget expenditures for increased services, change in natural population relative to the whole population, number of persons, who are at working age with reduced working capacity, employed for the first time).

Only $\mathrm{X}$ will be interpreted further, since it is a reason why the regions of Lithuania have one or another level of the shadow economy. Hence, the "shadow" estimated by the regional indicators of the shadow economy will be affected by the indicators mentioned above.

By setting the shadow economy equation, the scope of the shadow economy in each of the selected cities continues to be calculated.

SHADOW_t $\backslash$ SHADOW_average_year * from average year real value

In order to calculate fixed percentage of shadow economy SHADOW_average_year means have been taken from the year of 2014 of respective municipalities and percent (27.1 proc.) of shadow from the whole Lithuania from the year of 2014 (see Appendixes).

As seen from received (8) equation X2 (share of indirect taxes in Lithuania) reduced the level of shadow economy during the year of 2012 - 2015 (unlike in scientific studies, where the tax burden is expressed as personal income tax, payroll taxes, and/or indirect taxes, increase the level of shadow economy level, a positive sign is received).

Indirect taxes (X2) - taxes on income that the taxpayer pays are not when receiving income, but when spending them, meaning that they are paid when purchasing goods and services. Indirect taxes include value added tax, sales tax and excise duties.

According to the existing legal acts of the Republic of Lithuania, the Lithuanian Government solves the problem of shadow economy through the prism of increase direct and indirect taxes. This was demonstrated by calculations, covering the year of 2012-2015. Received X2 weight coefficient with minus sign (-2.167). Value Added Tax in
Lithuania is 21 proc. This tariff applies to all goods or services, sold in the territory of the country, if they are not subject to a reduced rate, and if these goods and services are sold by the VAT payer. The $21 \%$ consumption tax rate on a global scale is relatively high, but compared to other EU countries with high taxes, it more or less reflects the average. The lowest VAT rate in the EU is $17 \%$ in Luxembourg and the highest is $27 \%$ in Hungary. The minimum standard VAT rate can be $17 \%$, the maximum is $27 \%$ in the EU Member States. If a state of EU wanted to stand out among other members, it would have been difficult since free movement of goods is regulated within the EU commonly. If goods in one country were significantly more expensive than neighbours', online and other trade from neighbouring countries would increase. Collection of VAT in Lithuania has increased, 4.4 percent of VAT was collected in 2015 or $121 \mathrm{mln}$ Eur more than in 2014.

The impact of indirect tax on the size of the shadow economy is also justified by the program of the Government of the Republic of Lithuania (No. 2017-04172), where it is stated, that "upon adoption of amendments to the Law on Excise Duty of the Republic of Lithuania, from $1^{\text {st }}$ March, 2017 increased the rates of excise duty for all types of alcoholic beverages and ethyl alcohol: beer - around 112 percent, wine, other fermented beverages and intermediate products - around 92-111 percent, ethyl alcohol - around 23 percent. What is more, in order to ensure compliance of the excise duty rate for cigarettes with the minimum level of excise duty imposed by EU legislation (90 Eur for 1000 cigarettes), from $1^{\text {st }}$ March, 2017 increased cigarette excises in order to avoid the effect of substitutability for cigars and cigarillos".

The main problem with excise goods is their affordability. It is one of the smallest in the EU. Taking into account the population's income, tolerance to illegal production, the neighbourhood with Russia and Belarus and the state's ability to control the entrance of illegal products on the market, it is relevant to review the collection of excise taxes in Lithuania, where illegal products are widely spread on the market.

Average income (X3) have reduced the level of shadow economy in Lithuania during analysed timeframe (weight coefficient equal to -0.00126). During four years, the average wage in examined cities has gradually increased (for example, based on data from Statistics Lithuania, average income was 491 Eur a month in Druskininkai, in 2012, whereas 573 Eur a month in 2015 and in other cities the average income growth trend has been maintained). According to scientific studies, rising average incomes undoubtedly reduce the level of the shadow economy. 
Rita Remeikiene, Zoltan Rozsa, Ligita Gaspareniene, Viktoras Chadysas, Romualdas Ginevicius. Regional Estimates of the ...

X5 - L2 (consisting of average area of $\mathrm{m}^{2}$, number of motorcycle per 1000 population mean, number of smuggling cases recorded per 1000 population mean, number of women per 1000 men at the beginning of the year, mean). X 5 weight coefficient has been received negative and equal to -0.0955 , which means that it reduces the level of shadow economy.

The increase of recording smuggling cases shows that the work of public authorities, responsible for smuggling (customs, the criminal police unit) is effective in fighting with the shadow. Other indicator, included into L2 is the number of women per 1000 men, which shows specifics of women' behaviour and lifestyle in terms of informal employment, illegal consumption of goods, tax evasion compared to male gender. An assumption can be made, that the average living space per inhabitant and the number of motorcycles per 1000 inhabitants suggests that the factors mentioned decrease the level of the shadow economy.

X6 - L4 (composed of crime, expressed through the number of suspected/accused persons, who have conducted criminal offences per 1000 inhabitants; children at social risk (children living in social risk families, at the end of the year); the number of tourists (tourists with accommodation per 1000 inhabitants)). Weight coefficient for X6 is received positive and equal to 0.0911 , meaning that it increases the level of shadow economy. X6, which is composed of three indicators, reveals social environment of a city and the level of its attractiveness for foreigners/locals.

Social risk families are one of the biggest problems in Lithuania. The worst situation is in the cities of Rietavas and Radviliškis. There are also clear differences between cities and regions, in almost all districts, the ratio of social risk families is much higher than in big cities. The main problems in social risk families are related to alcoholism, lack of social workers and psychologists, shortage of day centres or their absence, smuggling of illegal goods through the border of Lithuania and Russia, and involvement of minors in this illegal activity.

The number of criminal offences in a given city reflects the city's ability to deal with crime and reveals the level of the city's security and contributes to the formation of attractiveness image for tourists and investors. The last indicator - the number of tourists with accommodation has an impact on the level of the shadow economy, according to the calculated beta value (-0.547), the number of tourists reduces the "shadow".

\section{Conclusions and Recommendations}

After empirical calculations, the causal factors, affecting the scale of shadow economy in separate regions of Lithuania (Aukstaitija, Dzukija, Suvalkija, Zemaitija) are determined. During the year of 2012-2015 the share of indirect taxes, average incomes, cases of cigarette smuggling, female population per 1000 men, the number of criminal offences, the number of children in social risk families and the number of tourists are the main reasons, influencing the scale of shadow economy in the analysed regions. In 2015 Panevezys had the highest "shadow" in Aukstaitija region with 28.6 percent (1.5 percent higher than overall level of shadow economy in the whole country), the lowest percent of shadow economy level was assessed in Visaginas with 25.1 percent. In Zemaitija region the highest "shadow" was in Silale and Kelme (each 28.6 percent), the lowest "shadow" was in Raseiniai (28.1 percent). In Dzukija region the highest shadow economy level was determined in Druskininkai with 27.7 percent, the lowest percent in Salcininkai (26.3 percent) and in Suvalkija region Marijampole had the highest "shadow" (28.8 proc.), Prienai had the lowest "shadow" (27.7 percent). According to Schneider's calculations, the overall level of the shadow economy in Lithuania in 2015 was 25.8 percent, whereas the calculations of the level of shadow economy in regions have revealed, that the level of shadow economy is much higher even in cities, where "shadow" has been the lowest in researched region. Identified reasons allow formulating the following recommendations for responsible authorities:

1) Increase efficiency in tax system, since current excise tax policy has a positive impact on the level of poverty, especially at regional level, deepening of social problems, which as a result contribute to the growth of shadow economy;

2) Encourage women' occupancy, emancipation and attract funding from national and international projects, to promote equal rights in researched regions;

3) Increase the level of attractiveness and security level in cities, promote FDI to cities, and effectively use money from EU Structural Funds.

Summarising, the authors make an assumption, that municipalities could review the content of their strategic plans, focusing on deeper researches of identified causes and reasons.

\section{Annexes}

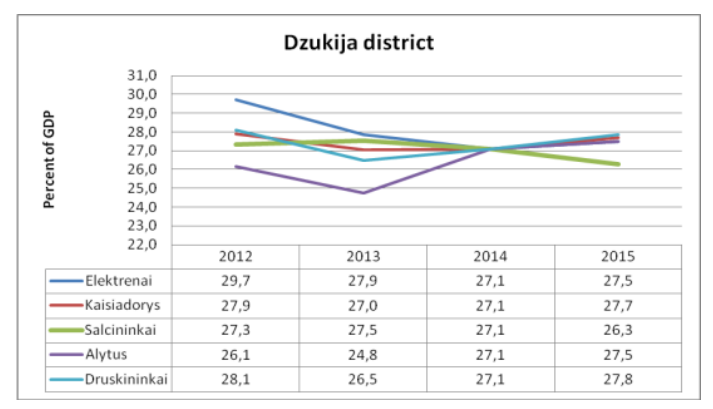

Figure 1. The Dynamics of the Shadow Economy, Percent of GDP in Dzukija District (Source: own's calculations)

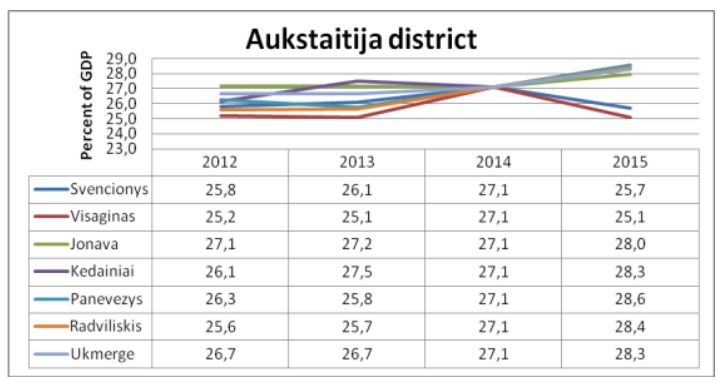

Figure 2. The Dynamics of the Shadow Economy, Percent of GDP in Aukstaitija District (Source: own's calculations) 


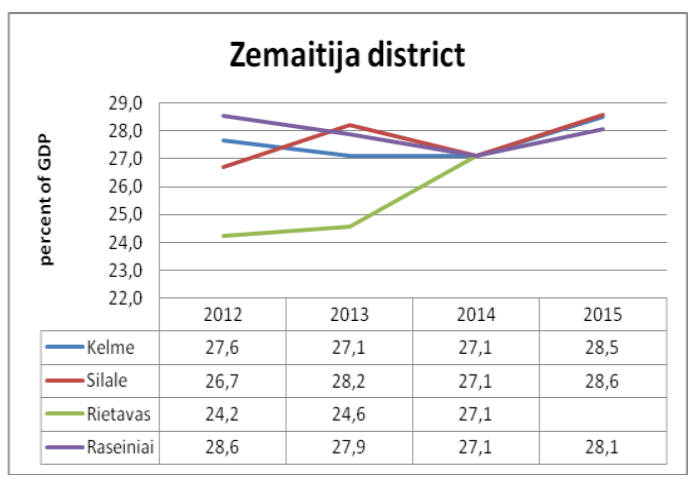

Figure 3. The Dynamics of the Shadow Economy, Percent of GDP in Zemaitija District (Source: own's calculations)

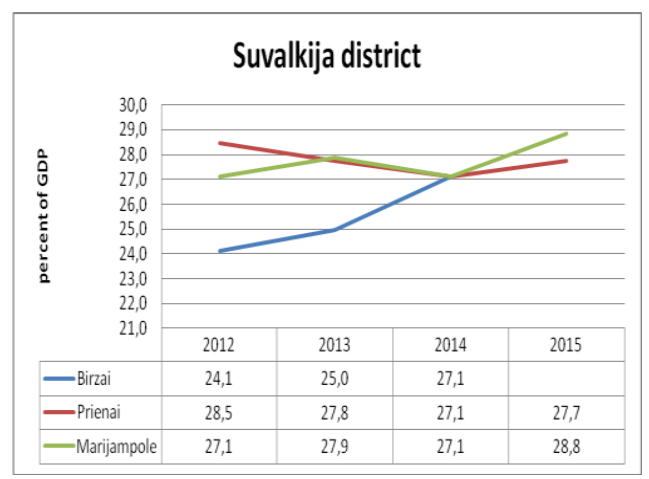

Figure 4. The Dynamics of the Shadow Economy, Percent of GDP in Suvalkija District (Source: own's calculations)

\section{References}

Adair, P. (2012). Non-Observed Economy in the European Union Countries (EU-15): A Comparative Analysis of Estimates. In Tax Evasion and the Shadow Economy, edited by M. Pickhardt and A. Prinz, 89-126. Cheltenham: Edward Elgar. https://doi.org/10.4337/9781781006740.00014

Alanon-Pardo, A., \& Gomez-Antonio, M. (2005). Estimating the Size of the Shadow Economy in Spain: A Structural Model with Latent Variables. Applied Economics 37 (9), 1011-1025. https://doi.org/10.1080/00036840500081788

Bilonizhko, O. (2006). Measurement and determinants of the hidden economy in regions of Ukraine and Russia: MIMIC approach. Available from Internet: http://www.kse.org.ua/uploads/file/library/2006/bilonizhko.pdf

Breusch, T. (2005a). The Canadian Underground Economy: an Examination of Giles and Tedds. Canadian Tax Journal 53 (2), 367-391.

Breusch, T. (2005b.) Australia's Cash Economy: are the Estimates Credible? The Economic Record 81, 394-403. doi:10.1111/ecor.2005.81.issue-255.

Breusch, T. (2005c). Fragility of Tanzi's Method of Estimating the Underground Economy. Working Paper, The School of Economics. Canberra: The Australian National University.

Breusch, T. (2005d). Estimating the Underground Economy Using MIMIC Models. Working Paper, The School of Economics. Canberra: The Australian National University.

Bucek, J. (2017). Determinants of the shadow economy in the Czech Regions: a region-level study. Review of Economic Perspectives, 3, 315-329. https://doi.org/10.1515/revecp-2017-0016

Buehn, A. (2011). The shadow economy in German regions: an empirical assessment, German Economic Review, 13(3), 275-290. https://doi.org/10.1111/j.1468-0475.2011.00557.x

Buszko, A. (2017). The level of shadow economy in Warminsko-Mazurski and Kujawsko-Pomorski regions, Copernican Journal of Finance \& Accounting, 6(4), 9-21. https://doi.org/10.12775/CJFA.2017.020

Cagan, P. (1958). The demand for currency relative to the total money supply, Journal of Political Economy, 66(4), 1-37. https://doi.org/10.1086/258056

Chaudhuri, K., Schneider, F., \& Chattopadhyay, S. (2006). The Size and Development of the Shadow Economy: an Empirical Investigation from States of India. Journal of Development Economics 80 (2), 428-443. https://doi.org/10.1016/j.jdeveco.2005.02.011

Dell'Anno, R. (2003). Estimating the Shadow Economy in Italy: A Structural Equation Approach, Working Paper 2003-7, Department of Economics, University of Aarhus.

Dell'Anno, R. (2007). The Shadow Economy in Portugal: an Analysis with the MIMIC Approach. Journal of Applied Economics 10 (2), 253-277.

Dell'Anno, R., Solomon, O. H. (2008). Shadow Economy and Unemployment Rate in USA: Is There a Structural Relationship? An Empirical Analysis. Applied Economics 40 (19), 2537-2555. https://doi.org/10.1080/00036840600970195

Dias, S., \& Samson, M. (2016). Informal Economy Monitoring Study Sector Report: Waste Pickers. Cambridge, MA, USA: WIEGO. Available from Internet: http://wiego.org/sites/wiego.org/files/publications/files/Dias-Samson-IEMSWaste-Picker-SectorReport.pdf

Fertala, N. (2008). The shadow of death: do regional differences matter for firm survival across native and immigrant entrepreneurs? Empirica 35 (1), 59-80. https://doi.org/10.1007/s10663-007-9051-2 
Rita Remeikiene, Zoltan Rozsa, Ligita Gaspareniene, Viktoras Chadysas, Romualdas Ginevicius. Regional Estimates of the ...

Gaspareniene, L., Remeikiene, R., \& Schneider, F. (2017). Concept, motives and channels of digital shadow economy: consumers' attitude. Journal of Business Economics and Management, 18(2), $273-287$. https://doi.org/10.3846/16111699.2016.1214620

Giles, D. E. A. (1999). Modelling the Hidden Economy and the Tax-Gap in New Zealand. Empirical Economics 24(4): 621 - 640. https://doi.org/10.1007/s001810050076

Giles, D. E. A., \& Tedds, L. M. (2002). Comments on Taxes and Canadian Underground Economy. Canadian Tax Journal $50(5), 1639-1667$.

Gonzalez-Fernandez, M., \& Gonzalez-Velasco, C. (2015). Analysis of the shadow economy in the Spanish regions. Journal of Policy Modeling, 37(6), 1049-1064. https://doi.org/10.1016/j.jpolmod.2015.09.006

Gutmann, P. M. (1977). The Subterranean Economy. Financial Analysts Journal 35, 26-34. https://doi.org/10.246 9/faj.v33.n6.26

Herwartz, H., Tafenau, E., \& Schneider, F. (2010) One Share Fits All? Regional Variations in the Extent of the Shadow Economy in Europe. Available from Internet: http://www.profpetersen.de/HGPHomepage/projekte/schattenwirtschaft/Working\%20Group\%203/02\%20Herwartz_Schneider_Tafenau_One_share_fit s_all_potsdam2010.pdf

Herwartz, H., Tafenau, E., \& Schneider, F. (2015) One Share Fits All? Regional Variations in the Extent of the Shadow Economy in Europe. Regional Studies, 49(9), 1575-1587. https://doi.org/10.1080/00343404.2013.848034

Kazemier, B. (2006). Monitoring the Underground Economy - A Survey of Methods and Estimates. In Jahrbuch Schattenwirtschaft 2006/2007, edited by D. Enste and F. Schneider, 11-53. Vienna: LIT.

Kireenko, A., Ivanov, I., Nevzorova, E., \& Polyakova, O. (2016). Shadow economy in the regions of the Russian Federation and the Ukraine. New Trends in Finance and Accounting, 17, 301-312.

Krakowski, M. (2005). Determinants of Informal Economy: the importance of regional factors. Discussion paper 313 , p. 30. Available from Internet: https://ageconsearch.umn.edu/bitstream/26313/1/dp050313.pdf. https://doi.org/10.21 39/ssrn.704267

Li, Y., Wang, J., Liu, Y., \& Long, H. (2014). Problem regions and regional problems of socio- economic development in China: A perspective from the coordinated development of industrialization, informatization, urbanization and agricultural modernization. Journal of Geographical Sciences, 24(6), 1115-1130. https://doi.org/10.1007/s11442-014$1142-y$

Li, Z., Li, J., \& He, B. (2018). Does foreign direct investment enhance or inhibit regional innovation efficiency? Evidence from China. Chinese Management Studies, 12(1), 35-55. https://doi.org/10.1108/CMS-02-2017-0034

Liu, H., Chen, Y., \& Long, H. (2011). Regional diversity of peasant household response to new countryside construction based on field survey in Eastern costal China. Journal of Geographical Sciences, 21(5), 869-881. https://doi.org/10.1007/s11442-011-0886-x

Mauleon, I., \& Sarda, J. (2017) Unemployment and the shadow economy. Applied Economics, 49(37), 3729-3740. https://doi.org/10.1080/00036846.2016.1267844

Medina, L., \& Schneider, F. (2017). Shadow economies around the world: new results for 158 countries over $1991-2015$. Available from Internet: http://www.econ.jku.at/members/Schneider/files/publications/2017/JointPaper_Leandro Medina_158countries.pdf

Na, L., \& Lightfoot, W. S. (2006). Determinants of foreign direct investment at the regional level in China. Journal of Technology Management in China, 1(2), 262-278. https://doi.org/10.1108/17468770610704930

Nchor, D., \& Adamec, V. (2015). Unofficial Economy Estimation by the MIMIC Model: the Case of Kenya, Namibia, Ghana and Nigeria. Acta Universitatis Agriculturae et Silviculturae Mendelianae Brunensis 63(6), 2043-2049. https://doi.org/10.11118/actaun201563062043

Phillip Morris International (2016). Project Sun. A study of the illicit cigarette market in the European Union. Norway and Switzerland, p. 232.

Pick, D., Dayaram, K., \& Butler, B. (2010). Regional development and global capitalism: the case of the Pilbara, Western Australia. Society and Business Review, 5(1), 99-110. https://doi.org/10.1108/17465681011017282

Pickhardt, M., \& Shinnick, E. (2008). Governance and Illicit Activities: A Survey of Recent Issues and Developments. In The Shadow Economy, Corruption and Governance, edited by M. Pickhardt and E. Shinnick, 3-17.Cheltenham: Edward Elgar.

Ramasamy, M., Dhanapal, D., \& Murugesan, P. (2017). Effects of FDI spillover on national productivity: evidence from panel data analysis using stochastic frontier analysis. International Journal of Emerging Markets, 12(3), 427-446. https://doi.org/10.1108/IJoEM-11-2015-0246

Schneider, F. (2007). Shadow economies and corruption all over the world: new estimates for 145 countries. Economics: the Open-Access, Open-Assessment E-Journal, 1, 1-66. 
Schneider, F. (2012). The Shadow Economy and Work in the Shadow: What Do We (Not) Know? IZA DP No. 6423 Available from Internet: http://ftp.iza.org/dp6423.pdf

Schneider, F., \& Enste, D. H. (2000). Shadow Economies: Size, Causes, and Consequences. Journal of Economic Literature 38, 77-114. https://doi.org/10.1257/jel.38.1.77

Schneider, F., Buehn, A., \& Montenegro, C. E. (2009). Shadow economy all over the world: new estimates for 162 countries from 1999 to 2007. Available from Internet: 2009/ShadowEconomyBuehnMontenegro/SHADOW ECONOMIES_011209.doc

Schneider, F., \& Buehn, A. (2016). Estimating the Size of Shadow Economy: Methods, Problems and Open questions. IZA Discussion Paper No. 9820. Available from Internet: http://ftp.iza.org/dp9820.pdf

Schneider, F., \& Williams, C. (2016). The shadow economy. Publisher: The Institute of Economics Affairs, p. 96. Available from Internet: https://iea.org.uk/wp-content/uploads/2016/07/IEA\%20Shadow\%20Economy\%20web \%20rev\%207.6.13.pdf

Schneider, F., Raczkowski, K., \& Mroz, B. (2015). Shadow economy and tax evasion in the EU. Journal of Money Laundering Control, 18(1), 34-51. https://doi.org/10.1108/JMLC-09-2014-0027

Schneider, F. (2016). Estimating a shadow economy: knowledges and problems. Slides.

Tafenau, E., Herwartz, H., \& Schneider, F. (2010) Regional Estimates of the Shadow Economy in Europe. International Economic Journal, 24(4), 629-636. https://doi.org/10.1080/10168737.2010.526010

United Nations (2008). Non-observed Economy in National Accounts: Survey of Country Practices (New York and Geneva: United Nations Economic Commission for Europe).

Vorobyev, P. (2015). Estimating informal economy share in Russian regions, Economics, Education and Research Consortium, Working Paper No. E15/02, 1-45.

Williams, C. C. (2011). Reconceptualising men's and women's undeclared work: evidence from Europe. Gender, Work \& Organisation 18(4), 415-37. https://doi.org/10.1111/j.1468-0432.2009.00466.x

The article has been reviewed.

Received in November, 2017; accepted in October, 2018. 